\title{
PERENCANAAN DAN PERSIAPAN MENGHADAPI MASA PENSIUN
}

\author{
Siti Nurina Hakim \\ Fakultas Psikologi \\ Universitas Muhammadiyah Surakarta
}

\section{ABSTRACT}

This activity aims at proposing the contemplation and necessary treatment to prepare workers in facing their retirement period so that they may get rid of their anxiety which may disturb their life. Therefore, the management of an institution should give necessary training for their workers to prepare their retirement period (MPP). This activity is conducted using some methods as speech, discussion, and consultation. The solution is taken from the participants since they are aware of their own needs, wants, abilities and obstacles. The solution from the participants is expected to be conducted and applied easily, since they obviously tend to obey the commitment created by them. After conducting this activity, there are some significant changes in discourse from the participants in terms of retirement condition, the next activities to be committed and how to start a new activity.

Kata kunci: masa pensiun, post power syndrome, stase, penyesuaian, aktivitas

\section{PENDAHULUAN}

Individu yang bekerja, baik pada sektor pemerintahan maupun swasta, pada saatnya nanti pasti akan mengalami suatu klimaks dalam pekerjaannya. Klimaks kerja masing-masing individu dipengaruhi oleh banyak faktor, dan masing-masing faktor mempunyai interaksi yang berbeda-beda antara individu satu dengan yang lain, karena ada individual differences dalam masing-masing individu. Salah satu hal yang pasti adalah bahwa pada setiap individu yang memasuki masa dewasa akhir atau masa lanjut usia pasti akan mengalami berbagai perubahan, termasuk dalam hal ini adalah terjadinya perubahan dalam hal kekuatan dan ketahanan kerja. Meskipun demikian, terjadinya perubahan kekuatan dan ketahanan kerja tetap bersifat relatif pada kehidupan masingmasing individu.

96 WARTA, Vol. 10, No. 1, Maret 2007: 96 - 109 
Suatu kondisi psikologis yang terjadi pada setiap pekerja yang mengalami dan merasa sudah tiba saatnya untuk berhenti bekerja (pensiun) tentu saja juga tidak sama. Pensiun oleh beberapa pekerja dapat dianggap sebagai suatu masa yang dinanti-nantikan, tetapi juga ada yang menganggap sebagai suatu masa yang mencemaskan, sehingga tidak tahu apa yang akan dilakukannya kelak apabila dirinya pensiun. Beberapa hal yang menyebabkan kecemasannya datang diantaranya adalah : belum tahu apa yang akan dikerjakannya di rumah, penghasilan yang diterimanya akan menurun dari penghasilannya saat ini, kesempatan bertemu dengan teman-teman kerjanya sudah seperti terputus, bagi yang mempunyai jabatan sudah tidak akan menerima "perlakuan" istimewa lagi (seperti berbagai fasilitas yang dirasakannya saat masih bekerja), dll. Individu yang mengalami hal-hal demikian dapat dikatakan sedang mengalami Post Power Syndrome, yaitu suatu sindroma kecemasan yang dialami oleh seseorang yang kehilangan kekuasaan (power).

Gambaran diatas menuntut adanya suatu pemikiran dan tindakan yang perlu dipersiapkan dan direncanakan secara matang bagi seorang pekerja untuk menghadapi masa pensiun ini, sehingga dapat terhindar dari kecemasan yang berkepanjangan yang dapat mengaganggu kehidupan selanjutnya yang idealnya klimaks itu happy end. Untuk itu pihak manajemen suatu instansi perlu memberi bekal cara-cara mempersiapkan dan merencanakan bagi para pekerjanya yang sudah memasuki masa persiapan pensiun (MPP).

Tujuan pengabdian masyarakat ini adalah::

1. Mensosialisasikan tentang apa tujuan instansi menerapkan masa pensiun bagi pegawai

2. Memberikan gambaran tentang apa saja hak-hak dan kewajiban yang masih melekat kepadanya

3. Melakukan deteksi akan bagaimana perasaan, apa kebutuhan, keinginan dan rencana kegiatan yang akan dilakukan oleh pekerja yang memasuki masa pensiun

Sedangkan manfaatnya adalah

1. Peserta memahami tujuan dan alasan suatu instansi menerapkan masa pensiun bagi pegawai

2. Peserta menjadi mengatahui apa saja hak dan kewajiban yang masih melekat kepadanya setelah pensiun

3. Menambah wacana tentang bagaimana perasaan, dan apa saja sebenarnya kebutuhan, keinginan dan rencana kegiatan yang akan dilakukan oleh pekerja yang memasuki masa pensiun 


\section{TINJAUAN PUSTAKA}

Pengertian pensiun, dalam Kamus Besar Bahasa Indonesia (1994) adalah tidakbekerja lagi karena selesai dinasnya. Turner dan Helms (1991) menjelaskan pensiun sebagai suatu akhir dari tugas suatu pekerjaan formal dan awal dari suatu peran baru dalam kehidupan, diantaranya berupa harapan perilaku selanjutnya dan bagaimana melakukan mendefinisi ulang (redefini) atas diri (self). Kedua penjelasan tentang pensiun di atas sudah cukup mewakili untuk mengerti apa itu sebenarnya pensiun, yang dapat disimpulkan sebagai suatu akhir dari tugas satu yang sifatnya formal untuk kemudian mengahadapi tugas berikutnya.

Ada dua macam jenis pensiun, yaitu pensiun dini dan pensiun reguler, semuanya membutuhkan suatu perencanaan dan persiapan. Banyak penelitian yang menhasilkan data bahwa setiap pensiun pasti akan membawa dampak pada individu yang menjalaninya, baik dampak psikologis, sosial, ekonomi, dll. sehingga berbagai perencanaan dan persiapan yang perlu dilakukan adalah juga mencakup aspek-aspek tersebut. Tanpa ada suatu perencanaan dan persiapan, pensiun dapat menimbulkan suatu kondisi yang penuh tekanan/stress seperti hasil penelitian yang dilaporkan oleh Mathews dkk. (1982), Mattila dkk. (1989), Aldwin (1990) dan juga Bosse dkk. (1991), sehingga penisun harus difahami secara proporsional dengan pemahaman secara baik dan benar terhadap faktor-faktor yang menyebabkan stressfull tersebut.

\section{Alasan Individu Dipensiun}

Ada beberapa alasan mengapa individu dipensiun yang dikemukakan oleh Turner \& Helms (1991) yang mendasarkan pada beberapa mitos atau stereotipe kuat di negara-negara Barat tentang pekerja lanjut usia, diantaranya adalah:

1. Pekerja lanjut usia adalah pekerja yang lambat dalam bekerja, kurang (bahkan tidak dapat) memenuhi persyaratan standar produktivitas yang ditentukan perusahaan

2. Pekerja lanjut usia terlalu sering tidak masuk kerja (absent)

3. Pekerja lanjut usia secara fisik kurang dapat memenuhi kebutuhan perusahaan

4. Pekerja lanjut usia banyak yang tidak fleksibel, sulit dilatih dan dikembangkan karena mereka sulit untuk dapat menerima perubahan

5. Gaji pekerja lanjut usia akan menmbah beban perusahaan, yang rasionya sudah tidak realistis lagi dengan peningkatan kinerjanya

98 WARTA, Vol. 10, No. 1, Maret 2007: 96 - 109 
Pertimbangan lainnya adalah adanya suatu realita bahwa partisipasi kekuatan kerja individu lanjut usia sekarang ini sangatlah rendah dan terjadi penurunan dari tahun ke tahun, tahun 1936 ada 68,4\%, tahun 1940 ada 41,86\% dan tahun 1994 tinggal 16,8\%. Kondisi tersebut merupakan dasar bagi pemerintah untuk menentukan usia pensiun dan juga perlu membatasi pekerja lanjut usia.

\section{Stase Pensiun}

Pensiun bukanlah suatu tahap atau stase yang datang dengan tiba-tiba, melainkan suatu tahap yang telah melalui proses dengan berbagai fase. Proses dalam menuju pensiun itu, banyak yang masih kurang mengerti dan mengetahui bagaimana proses pensiun itu. Proses yang terjadi beserta stase-stasenya, tidak mutlak dialami oleh setiap individu, melainkan tergantung pada diri individu itu sendiri. Kecuali itu, setiap stase yang dialami oleh individu tidak selalu berurutan, dapat melompat. Idealnya, sebelum individu memasuki masa pensiun telah memehami dan mengerti bagaimana menyikapi pensiun, apa itu kebijakan pensiun dan faktor-faktor yang mempengaruhi keputusan pensiun. Sebagai pelengkap wawasan, berikut dikemukakan pendapat Robert Atchley dan juga pendapat Williamson, Monley dan Evans (dalam Turner, 1982; Rybash dkk., 1991) yang mengemukakan beberapa stase dalam masa menjelang pensiun dan masa pensiun itu sendiri, yaitu:

1. Stase Pra-Pensiun

Stase ini dibagi menjadi dua, yaitu remote stage (jangka panjang) dan near stage (jangka pendek). Stase ini seringkali disiapkan dengan program masa persiapan pensiun (pre-retirement) yang menuntut peran serta aktif dari individu yang hendak pensiun dan keluarganya, sehingga individu dan keluarganya akan benar-benar siap saat masa pensiunnya tiba. Prediktor utama terhadap sikap pada pensiun yang paling sering dipergunakan adalah kesehatan fisik dan penghasilan.

\section{Stase Honeymoon}

Merupakan stase pertama saat inidivdu benar-benar memasuki masa pensiun, seringkali ditandai dengan rasa euforia yang muncul karena merasakan adanya suatu kebebasan baru. Stase ini panjang pendeknya ditentukan oleh individunya sendiri serta bagaimana memanfaatkannya. 
3. Stase Disengagement (stase yang tidak menyenangkan)

Stase ini dikatakan juga sebagai suatu stase pelepasan. Pada stase ini (terutama pada individu yang pernah menduduki jabatan yang tinggi) cenderung mengalami post power syndrome, dan tingkat kedalaman stase ini terkait dengan menurunnya kondisi kesehatan, keterbatasan finansial, dan kurang mengerti akan kondisi dirinya sendiri. Individu sering mengalami gangguan-gangguan dalam hubungan persahabatan (relationship).

4. Stase Re-Orientation

Individu yang memasuki masa pensiun dan tidak pernah mendapatkan banyak batu sandungan atau hambatan, perlu melakukan re-orientasi untuk menyesuaikan diri terhadap situasi baru. Pada stase re-orientasi ini banyak pensiunan yang mampu berperan aktif dalam berbagai kegiatan, sehingga dapat saling membantu dengan pensiunan lainnya secara formal maupun informal, misalnya dengan adanya organisasi retired senior volunteer programe (program sukarela pensiunan senior).

\section{Stase Stabilitas}

Istilah stabilitas dalam hal ini diartikan dengan adanya keajegan kriteria atas keberhasilan individu dalam menghadapi perubahan yang terjadi. Stase ini dicapai oleh individu yang sudah mampu menetapkan pilihan (-pilihan) apa yang akan dikerjakan atau dilakukan pada saat dirinya pensiun, diikuti dengan pelaksanaan atas pilihannya dan mampu menikmati kehidupan dan performansinya.

\section{Stase Terminasi}

Stase ini terjadi pada pensiunan yang disebabkan oleh sakit dan ketidakberdayaan atau ketidakmampuannya karena kondisi usia lanjut. Terjadi suatu peralihan peran ke individu yang sakit dan tidak mampu melakukan apa-apa lagi, kondisi ini terjadi tergantung pada kondisi fisik dan otonomi diri individu.

Faktor-faktor yang dianggap berhubungan dengan stress pada pensiunan secara garis besar dapat dikelompokkan menjadi tiga, yaitu faktor kesehatan, penghasilan dan pensiun yang tidak diharapkan. Faktor unik yang berhubungan dengan stress pensiun adalah dalam hal hubungan perkawinan yang oleh karenanya disebut dengan the husband underfoot syndrome yang kebanyakan malah menyerang kaum istri sang pensiunan.

100 WARTA, Vol. 10, No. 1, Maret 2007: 96 - 109 


\section{Pensiun dan Gaya Hidup}

Perubahan status dalam diri pensiunan menjadikan individu juga melakukan perubahan dalam gaya hidupnya. Hanstein dan Wapner (dalam Rybash dkk., 1991) menyebutkan empat cara pandang individu pada masa pensiun yang dapat mempengaruhi gaya hidupnya, yaitu:

1. Transition to Old Age, menjalani masa transisi dalam memasuki usia lanjut, ada perasaan bahwa pensiun merupakan suatu masa dimana terjadi pelepasan diri pada segala aktivitas, mereka akan sangat menikmati kondisi dan keadaan tersebut.

2. New Beginning, menganggap masa pensiun sebagai suatu masa datangnya kesempatan baru dalam kehidupan individu sehingga dapat mengembangkan hobi dan aktivitas lainnya yang selama ini dinikmati hanya kalau mempunyai waktu senggang.

3. Continuation, suatu masa dimana individu memiliki suatu kesempatan untuk melanjutkan aktivitasnya, baik dalam hal pekerjaan, hobi, dll lebih dikaitkan dengan keahliannya.

4. Impossed Disruption, sebagai suatu masa negatif, karena pensiun dipersepsi dengan kehilangan pekerjaan, teman-teman, dan hilangnya kesempatanuntuk berkarya.

Dukungan maupun sikap masyarakat di lingkungan individu pensiunan penting dalam menentukan perasaan dan harga diri individu pensiunan. Menurut Ekerdt (1986) dengan busy ethic-nya, agar para pensiunan tetap merasa berguna, maka mereka sebaiknya diberi kesempatan untuk menentukan aktivitas bermanfaat apa yang ingin diikutinya. Turner dan Helms 91991) menjelaskan beberapa penyesuaian yang dianjurkan untuk dilakukan oleh para pensiunan, maliputi :

\section{Penyesuaian Psikologis}

Peralihan dari suatu kehidupan kerja yang mempunyai suatu identitas signifikan ke suatu kehidupan tanpa pekerjaan yang memiliki identitas, membutuhkan suatu penyesuaian psikologis yang cukup sulit. Penyesuaian psikologis yang baik berarti mampu mengembangkan suatu gaya hidup yang berkesinambungan antara masa kini dengan masa lalunya serta mampu memenuhi kebutuhan jangka panjangnya, kesuksesannya ditandai dengan adanya resolusi yang harmonis. 


\section{Penyesuaian Penghasilan (baca: Keuangan)}

Gambaran pertama individu yang pensiun adalah akan berkurangnya penghasilan mereka. Banyak pensiunan yang membutuhkan penghasilan lebih dari sekedar untuk hidup layak. Russel Ward (1984) menemukan bahwa banyak para pensiunan yang merasakan ketidakstabilan keuangan pada awal kehidupan masa pensiunnya, mereka kebanyakan menghabiskan keuangannya untuk makan, perumahan dan perawatan kesehatan. Individu yang mengalamui masa pensiun, dan sudah memperhitungkan bahwa kondisi tersebut akan terjadi, keadaan itu tidak menjadi masalah yang cukup berarti baginya, ada hal lain yang tidak tergantikan oleh nilai uang secara riil yang saat ini dapat dikerjakannya setelah memasuki masa pensiun.

\section{Penyesuaian Sosial}

Pensiun secara signifikan berhubungan dengan berkurangnya kontak sosial hubungan kerja, kompensasinya adalah dengan mempererat hubungan pertemanan (friendship). Individu dapat melihat sisi positif dan sisi negatif dari berhentinya kerja ini terhadap hubungan sosialnya.

\section{MATERI DAN METODE PELAKSANAAN}

\section{A. Kerangka Pemecahan Masalah}

Memperhatikan uraian permasalahan yang telah dikemukakan sebelumnya, beberapa langkah yang dapat dilakukan oleh pihak-pihak yang tekait dengan pekerja sebelum mereka memasuki masa pensiun antara lain:

1 Melakukan sosialisasi tentang apa tujuan instansi menerapkan masa pensiun bagi pegawai

2 Memberikan gambaran tentang apa saja hak-hak dan kewajiban yang masih melekat kepadanya

3 Pihak instansi melakukan deteksi akan bagaimana perasaan, apa kebutuhan, keinginan dan rencana kegiatan yang akan dilakukan oleh pekerja yang memasuki masa pensiun.

\section{B. Realisasi Pemecahan Masalah}

Kegiatan ini dilaksanakan secara bertahap dengan strategi:

1) Sebelum pelaksanaan kegiatan dilakukan penjajakan tentang kondisi Pegawai yang memasuki MPP (peserta), dengan tujuan untuk mendapatkan gambaran tentang berapa aspek yang menjadi target sasaran kegiatan.

102 WARTA, Vol. 10, No. 1, Maret 2007: 96 - 109 
Hasil pelaksanaan strategi ini menunjukkan bahwa lebih dari separoh peserta belum mempunyai gambaran dan wacana tentang apa itu hak-haknya, bagaimana mendapatkan hak-haknya, apa aktivitas yang akan dilakukannya setelah pensiun, apa saja aktivitas yang akan dilakukan, bagaimana caracara memulai suatu usaha baru.

2) Setelah pelaksanaan kegiatan dilakukan penjajakan ulang untuk hal yang sama, dengan tujuan untuk melihat apakah para peserta kegiatan ini sudah mendapatkan wacana yang lebih jelas dan mempunyai pemikiran yang lebih terbuka.

Hasil pelaksaan strategi kedua menunjukkan sudah mulai ada perubahan dalam pemikiran peserta, terbukti setelah mendapatkan beberapa pengetahuan yang terkait dengan perencanaan dan persiapan menghadapi masa pensiun, para peserta telah mengerti akan hak-haknya, cara mendapatkan hak-haknya, dan orientasi aktivitas yang akan mereka lakukanpun terdapat perubahan.

\section{Khalayak Sasaran}

Mengingat permasalahan yang dihadapi oleh para peserta yang hendak memasuki masa pensiun sangat variatif dan berkaitan dengan berbagai hal, sehingga agar tujuan kegiatan ini lebih efektif sangatperlu dukungan dan kerjasama dengan berbagai pihak, terutama pihak instansi, pasangan hidup (suami/istri) pensiunan, dan para pekerja lain yang msih aktif. Peran serta pihak-pihak terkait tersebut sangatlah strategis sebagai sumber informasi dan sebagai sasaran antara dari kegiatan ini, sehingga data-data yang diperlukan dan hendak diungkap dengan peran serta pihak-pihak tersebut akan lebih akurat. Pihakpihak terkait dapat dilibatkan secara aktif, dan sebenarnya dapat berperan serta langsung atau tidak pada kegiatan ini, hanya saja pada kesempatan pelaksanaan kali ini pihak-pihak tersebut tidak dilibatkan secara langsung.

\section{Metode Kegiatan}

Langkah-langkah yang dilakukan sebelum kegiatan Pengabdian Masyarakat kali ini dilaksanakan adalah :

1. Penggalian data pekerja yang hendak memasuki masa pensiun, dengan tujuan kita mengetahui usianya, asal golongan, berasal dari jenis pekerjaan apa saja, dll.

2. Melakukan pengelompokan subjek/target sasaran ke dalam dua kelom- 
pok karena kegiatan dilakukan dalam dua shift, didasarkan pada kesamaan latar belakang yang dimiliki subjek.

3. Mendeteksi pemahaman peserta tentang seluk beluk pensiun, sebelum dan sesudah dilaksanakannya kegiatan ini.

Kegiatan Pengabdian Masyarakat ini sendiri dilaksanakan dengan menggunakan metode ceramah, diskusi, dan konsultasi. Metode yang kita pakai tersebut memungkinkan untuk didapatkannya sumber-sumber informasi dan permasalahan yang riil, sehingga diharapkan dapat saling sharing antar pekerja dan permasalahan yang ada dapat diatasi dan dapat menemukan solusinya sesuai dengan karakter pekerja itu sendiri.

Solusi sengaja kita gali dari para peserta sendiri, karena kita berasumsi bahwa merekalah yang mengerti akan kebutuhan dan keinginannya sendiri, kemampuan-kemampuan apa yang dimiliki dan hambatan-hambatan apa saja yang biasanya ditemui. Solusi yang berasal dari peserta sendiri diharap-kan lebih mudah untuk dijalani dan diterapkan, karena apabila suatu komit-men dibuat oleh dirinya sendiri kecenderungannya akan ditaati.

\section{HASIL DAN PEMBAHASAN}

\section{A. Hasil}

Pengelompokan peserta ditentukan berdasarkan golongan kepegawaiannya. Kelompok I adalah pegawai dari golongan II, sedangkan Kelompok II adalah pegawai dari golongan III. Hasil penerapan strategi pelaksaan kegiatan yang telah kita lakukan diperoleh suatu hasil seperti yang tercantum dalam tabel di bawah ini:

\section{Tabel 1.}

Kondisi Pemahaman Peserta tentang Pensiun

Sebelum Kegiatan

\begin{tabular}{|c|c|c|c|c|c|c|c|}
\hline \multirow{2}{*}{$\mathrm{NO}$} & \multirow{2}{*}{ ASPEK YANG DIUNGKAP } & \multicolumn{2}{|c|}{ SUDAH TAHU } & \multirow{2}{*}{$\mathrm{JML}$} & \multicolumn{2}{|c|}{ BELUM TAHU } & \multirow{2}{*}{ JML } \\
\hline & & KLP-I & KLP-II & & KLP-I & KLP-II & \\
\hline 1 & Hak-hak setelah pensiun & 11 & 26 & 37 & 27 & 18 & 45 \\
\hline 2 & Cara mendapatkan hak & 9 & 26 & 35 & 29 & 18 & 47 \\
\hline 3 & Gambaran aktivitas & 16 & 29 & 45 & 22 & 15 & 37 \\
\hline 4 & Wacana memulai usaha baru & 12 & 22 & 34 & 26 & 22 & 48 \\
\hline & JUMLAH & 48 & 103 & 151 & 104 & 73 & 177 \\
\hline
\end{tabular}

104 WARTA, Vol. 10, No. 1, Maret 2007: 96 - 109 
Hasil tersebut kemudian dikelola lebih lanjut untuk melihat kedalaman dari aspek ke-3 dan aspek ke-4, sehingga peserta yang dikenai pertanyaan pendalaman ini hanyalah peserta yang sudah tahu tentang aspek ke-3 dan ke4 jumlah keseluruhan ada 79 orang saja.

\section{Tabel 2.}

Gambaran Aktivitas dan Wacana Usaha pada Masa Pensiun Sebelum Kegiatan

\begin{tabular}{|c|l|c|c|c|}
\hline NO & \multicolumn{1}{|c|}{$\begin{array}{c}\text { ASPEK YANG } \\
\text { DIUNGKAP }\end{array}$} & $\begin{array}{c}\text { KELOMPOK } \\
\text { - I }\end{array}$ & $\begin{array}{c}\text { KELOMPOK } \\
\text { - II }\end{array}$ & JUMLAH \\
\hline 1 & $\begin{array}{l}\text { Menikmati lebih } \\
\text { dahulu masa pensiun }\end{array}$ & 9 & 20 & 29 \\
\hline 2 & $\begin{array}{l}\text { Berkunjung ke rumah } \\
\text { kerabat, anak-cucu }\end{array}$ & 7 & 9 & 16 \\
\hline 3 & $\begin{array}{l}\text { Memulai/merintis } \\
\text { usaha baru }\end{array}$ & 6 & 15 & 21 \\
\hline 4 & $\begin{array}{l}\text { Meneruskan/menekun } \\
\text { i usaha yang dimiliki }\end{array}$ & 6 & 7 & 13 \\
\hline \multicolumn{2}{r|}{ JUMLAH } & 28 & 51 & 79 \\
\hline
\end{tabular}

Setelah pelaksanaan kegiatan diperoleh suatu kemajuan yang cukup menakjubkan atas gambaran/peta pemahaman peserta terhadap seluk beluk pensiun dan aktivitasnya, termasuk kemampuan untuk memberikan gambaran yang lebih spesifik atas aktivitas yang ingin dan atau akan dilakukannya kelak.

Banyak pertanyaan, jawaban maupun saran yang diberikan oleh antar peserta, sehingga dalam kegiatan ini banyak terjadi interaksi dan dialog yang cukup menyegarkan dan mencerahkan wacana. Banyak alternatif aktivitas yang dapat dilakukan oleh mereka. Satu orang peserta sangat mungkin memiliki minat lebih dari satu jenis aktivitas. 
Tabel 3.

Kondisi Pemahaman Peserta tentang Pensiun Setelah Kegiatan

\begin{tabular}{|c|c|c|c|c|c|c|c|}
\hline \multirow[t]{2}{*}{ NO } & \multirow{2}{*}{$\begin{array}{c}\text { ASPEK YANG } \\
\text { DIUNGKAP }\end{array}$} & SUDAH & TAHU & \multirow[t]{2}{*}{ JML } & BELUM & TAHU & \multirow[t]{2}{*}{ JML } \\
\hline & & KLP-I & KLP-II & & KLP-I & KLP-II & \\
\hline 1 & Hak-hak setelah pensiun & 22 & 39 & 61 & 16 & 5 & 21 \\
\hline 2 & Cara mendapatkan hak & 27 & 36 & 63 & 11 & 8 & 19 \\
\hline 3 & Gambaran aktivitas & 30 & 40 & 70 & 8 & 4 & 12 \\
\hline 4 & $\begin{array}{l}\text { Wacana memulai usaha } \\
\text { baru }\end{array}$ & 27 & 38 & 65 & 11 & 6 & 17 \\
\hline & JUMLAH & 106 & 153 & 259 & 46 & 23 & 69 \\
\hline
\end{tabular}

Tabel 4.

Gambaran Aktivitas dan Wacana Usaha pada Masa Pensiun Setelah Kegiatan

\begin{tabular}{|c|l|c|c|c|}
\hline NO & \multicolumn{1}{|c|}{ ASPEK YANG DIUNGKAP } & KLP - I & KLP - II & JML \\
\hline 1 & Menikmati lebih dahu-lu masa pensiun & 5 & 9 & 14 \\
\hline 2 & Berkunjung ke rumah kerabat, anak-cucu & 25 & 31 & 56 \\
\hline 3 & Memulai/merintis usaha baru & 18 & 23 & 41 \\
\hline 4 & Meneruskan/menekuni usaha yang dimiliki & 9 & 15 & 24 \\
\hline \multicolumn{2}{r|}{ JUMLAH } & 57 & 78 & 135 \\
\hline
\end{tabular}

Tabel 5.

Spesifikasi Jenis Aktivitas dan Usaha Setelah

Masa Pensiun

\begin{tabular}{|c|l|c|c|c|}
\hline NO & JENIS AKTIVITAS USAHA & KLP - I & KLP - II & JUMLAH \\
\hline 1 & Aktif di Bidang Sosial & 10 & 14 & 24 \\
\hline 2 & Aktif di Bidang Agama & 21 & 25 & 46 \\
\hline 3 & Usaha Toko Kelontong & 15 & 20 & 35 \\
\hline 4 & Usaha Bidang Pertanian & 25 & 17 & 42 \\
\hline
\end{tabular}

106 WARTA, Vol. 10, No. 1, Maret 2007: 96 - 109 


\begin{tabular}{|c|l|c|c|c|}
5 & Usaha Warung/Jasa Makanan & 11 & 6 & 17 \\
\hline 6 & Usaha Jasa Jahit & 9 & 0 & 9 \\
\hline 7 & Usaha Transportasi & 5 & 16 & 21 \\
\hline 8 & Usaha Pelajaran Tambahan/Les & 26 & 17 & 43 \\
\hline 9 & Aktif Menulis & 20 & 32 & 52 \\
\hline 10 & Dll & 4 & 7 & 11 \\
\hline \multicolumn{2}{r|}{ JUMLAH } & 146 & 154 & 300 \\
\hline
\end{tabular}

\section{B. Pembahasan}

Hasil dari pelaksanaan kegiatan ini terhadap wacana dan pengetahuan para pegawai tentang pensiun dinilai sangat positif oleh peserta. Wacana pegawai yang semula belum memahami akan hak-haknya dan kondisi yang mungkin terjadi setelah yang bersangkutan menjalani masa pensiun ternyata berubah ke suatu wacana yang lebih terbuka. Wacana dasar yang ditargetkan adalah pegawai diharapkan lebih memahami akan kondisi dan hak yang diterimanya setelah pensiun, bagaimana cara-cara mendapatkan hak-haknaya tersebut. Wacana pegawai semakin bertambah luas ketika dilaku-kan suatu diskusi dan tanya jawab seputar aktivitas dan kegiatan yang dapat dilakukan oleh mereka setelah pensiun. Beberapa kendala maupun keterbatasan pengetahuan tentang kegiatan atau aktivitas menjadi semakin terbuka dan jelas dengan adanya sharing pengalaman antar peserta kegiatan ini, sehingga peserta yang semula hanya berfikir untuk melakukan satu kegiatan saja sekarang sudah semakin terbuka gambarannya untuk melakukan beberapa aktivitas yang menjadi minatnya.

\section{SIMPULAN DAN SARAN}

\section{A. Simpulan}

Kegiatan ini dirancang untuk mensosialisasikan atas kebijakan yang diambil oleh Pemerintah maupun Pengusaha dalam pemberhentian pegawainya oleh karena harus memasuki masa pensiun. Kegiatan ini dapat dinilai keberhasilannya apabila tujuan utama dapat tercapai, sehingga para pegawai yang telah mengikuti aktivitas pembekalan dengan tema Perencanaan dan Persiapan dalam Memasuki Masa Pensiun dari hasil pantauan evaluasi dengan angket yang disebarkan kepada peserta temyatatelah memperoleh suatu gambaran atas tingkat pemahaman 
pegawai tentang ketentuan pensiun kepada pegawai pada usia-usia tertentu ternyata cukup baik.

Kegiatan ini ternyata juga membuka suatu wacana baru bagi pelaksana maupun bagi peserta, bahwa ternyata sharing antar peserta dan penyelenggara kegiatan menambah suatu pemahaman akan aktivitas-aktivitas yang dapat dilakukan dan dikerjakannya, dengan berbagai variasi dari bentuk aktivitas, yang dapat membuka peluang bagi mereka yang berminat mengerjakannya untuk menambah penghasilannya. Wacana baru ini membuat para pegawai tidak berkecil hati lagi dengan berkurangnya pendapatan yang diberikan oleh pemerintah, karena ternyata pendapatnya bahkan daat lebih banyak lagi apabilamau melakukan aktivitas yang produktif.

\section{B. Saran}

Berdasarkan pada hasil evaluasi pada kegiatan ini, dan dengan pertimbangan bahwa bagaimanapun juga para pegawai yang telah memasuki masa pensiun membutuhkan suatu wacana yang lebih luas, maka diajukan beberapa saran, yaitu :

1. Kepada pihak perusahaan atau kantor pemerintahan hendaknya membuat suatu perencanaan kegiatan bagi para pegawainya yang masih aktif, sehingga apabila tiba saat memasuki MPP tidak terlalu sulit dalam mengarahkan para pegawainya.

2. Kepada pihak Lembaga Pengabdian Masyarakat Universitas Muhammadiyah Surakarta melalui Fakultas Psikologi, perlu meningkatkan keterlibatannya secara aktif dan langsung dalam melakukan pembinaan dan pembekalan bagi para pegawai di lingkungan Universitas Muhammadiyah Surakarta sendiri maupun di kantor-kantor pemerintahan maupun swasta.

3. Kegiatan pengabdian masyarakat serupa perlu ditindaklanjuti dengan berbagai kegiatan yang terkait, dengan langsung melibatkan mahasiswamasiswanya agar mereka dapat menerapkan ilmu pengetahuan yang diperolehnya, terutama mahasiswa Fakultas Psikologi Universitas Muhammadiyah Surakarta.

4. Kegiatan serupa dapat dilakukan dengan menjalin kerjasama yang baik dengan kantor-kantor pemerintah maupun kantor-kantor swasta.

108 WARTA, Vol. 10, No. 1, Maret 2007: 96 - 109 


\section{DAFTAR PUSTAKA}

Ekerdt, D.J. 1986. The Gerontologist. USA. WmC. Brown Publishers.

Quadagno, J. 1999. An Introduction to Gerontology, Aging and the Life Course. London. McGraw-Hill College.

Rybash, J.W., Roodin, P.A. and Santrock, J.W. 1991. Adult Development and Aging. USA. WmC Brown Publishers.

Turner, J.S. and Helms, D.B. 1991. Life-Span Development. $4^{\text {th }}$. London. Holt, Rinehart and Winstone, Inc. 
110 WARTA, Vol. 10, No. 1, Maret 2007: 96 - 109 